Article

\title{
Do Mobile Phones Help Expand Social Capital? An Empirical Case Study
}

\author{
Alain Shema * and Martha Garcia-Murillo \\ School of Information Studies, Syracuse University, Syracuse, NY 13244, USA; E-Mails: sralain@syr.edu (A.S.), \\ mgarciam@syr.edu (M.G.-M.) \\ * Corresponding author
}

Submitted: 30 October 2019 | Accepted: 3 February 2020 | Published: 14 May 2020

\begin{abstract}
The rapid adoption of mobile phones, particularly in developing countries, has led a number of researchers to investigate their impact on socioeconomic activity in the developing world. However, until the recent advent of smart communication devices, mobile phones were primarily a relations management technology that enabled people to stay connected with each other. In this article, we focus on this basic function and analyze how people use this technology as a tool to expand their social capital. We use a dataset containing more than three billion call detail records from Rwanda's largest telecommunication operator, covering the whole country during the period from 1 July 2014 to 31 March 2015, and combine these records with data from the fourth Integrated Household Living Conditions Survey conducted by the National Institute of Statistics of Rwanda in 2015. We found that people's calling patterns significantly correlated with the income level of their region, which also dictated the destinations of their calls, with middle-income regions acting as a link between the richest and the poorest regions. From these results, we propose a framework for understanding the role of mobile phones in the development of social capital.
\end{abstract}

\section{Keywords}

call detail records; mobile phones; telecommunications; network analysis; poverty; Rwanda; social capital

\section{Issue}

This article is part of the issue "Digital Inclusion Across the Globe: What Is Being Done to Tackle Digital Inequities?" edited by Bianca C. Reisdorf (University of North Carolina at Charlotte, USA) and Colin Rhinesmith (Simmons University, USA).

(C) 2020 by the authors; licensee Cogitatio (Lisbon, Portugal). This article is licensed under a Creative Commons Attribution 4.0 International License (CC BY).

\section{Introduction}

It has been presumed that mobile phones are a powerful technology that can empower the poor. This makes sense from a purely academic perspective; presumably, those who do not possess a phone can, upon acquiring one, have access to much more information and many more resources. However, some of the limited research on phones and social relations has found that the poor do not make many calls (Galperin \& Mariscal, 2007), and while some authors have found a positive relation with social capital (Islam, Habes, \& Alam, 2018; Shen \& Gong, 2019), others have found no change (Cibangu, Hepworth, \& Champion, 2017; Goodman, 2005; Matous, Tsuchiya, \& Ozawa, 2011). Having access to new data, namely, call detail records (CDRs), we set out to determine whether mobile phone communication in different economic re- gions in Rwanda furnished those in impoverished areas with access to people and resources beyond their local communities.

Much research has been done on the impact of mobile phones on economic activity (Abraham, 2006; Amel, 2014; Lee, 2009). However, even though this technology has been found to afford economic empowerment, much less has been written about this technology simply as a relational tool. A phone is a coordination technology whose primary purpose is to connect people; only recently has smartphone use expanded to embrace other functions. It is also the case that even though smartphone penetration has been growing (Silver, 2019; Silver et al., 2019), there are still many developing countries where, although they are available, smartphones are unaffordable. In Rwanda, for example, only $15 \%$ of the population possesses one (Collins, 2019). 
We decided to focus on the basic functions of this technology, namely calls and text messages (SMS), to explore the calling patterns of people in Rwanda. Our interest in mobile phones as a relational technology emanated from the fact that social relations impact economic factors. The number of relationships one has can limit or expand one's resources; thus, we adopted development theories and the concept of social capital-the connections among individuals that can build trust relations that can give access to resources-to construct the framework for this study.

The dataset used in the study contained more than three billion CDRs from Rwanda's largest telecommunication operator, covering a nine-month period from 1 July 2014 to 31 March 2015. We also used data from the fourth Integrated Household Living Conditions Survey conducted by the National Institute of Statistics Rwanda (NISR, 2015), to map calls to all the districts (administrative regions), grouped by their levels of poverty. These two datasets helped us examine whether or not mobile phones enable people to expand their social capital and access resources by connecting with people outside of their communities.

In the following section, we present a review of the literature, which begins by defining social capital and its benefits, and we address the connections among development, geography, and social capital. The third and fourth sections are dedicated to explaining the methodology and presenting the results. In the fifth section, the analysis is conducted, proposing a framework based on social connections and income. The final section, prior to concluding, offers some policy recommendations.

Our analysis found that mobile phones are a socially reinforcing technology, as the calling patterns of people mimic the types of relationships they appear to have in their face-to-face interactions. While we note that many studies have found that mobile technology has allowed people to grow economically, it appears that the economic gains may be limited by a person's social capital. In other words, technology enables certain activities that may not have been possible before, but we found that there were no dramatic changes in the participants' social capital; instead, there was a limited impact on social connections across populations from different economic strata.

\section{Related Work}

\subsection{Social Capital: Definition and Benefits}

The central concept of social capital is that social networks have value. The term has been defined in various ways by many authors; Coleman (1988), for example, defined social capital as a "social structure that facilitates certain actions of actors within such structure." For Narayan (2002), it is a relational concept that encompasses the norms and social relations embedded in the social structures of society that enable people to work together. Lin (1999) defined social capital as interpersonal networks (ties) that can provide access to resources. Emphasizing the relations and interdependence among individuals, Putnam later defined social capital as "connections among individuals, social networks and the norms of reciprocity and trustworthiness that arise from them" (Putnam, 2000, p. 19). In addition, however, there are related concepts that capture the notion of inclusion and participation in social and political processes, which are often missed in defining social capital. Table 1 summarizes the definitions of these concepts and highlights their common elements. Social capital is thus a factor that affects other aspects of inclusion.

The literature on social capital identifies three types: bonding, bridging, and linking (Lai \& Siu, 2006; Putnam, 2000). Bonding capital pertains to close personal relations of the type that normally exists among family members; it is based on strong trust relationships that have forged loyalty among the members. Bridging social capital represents the connections that people have beyond their immediate relationships-these can be acquaintances from the different social circles that people be-

Table 1. Definitions of social capital.

\begin{tabular}{lll}
\hline Term & Description & Authors \\
\hline Social capital & Basic human necessities & Sen (2000) \\
& Freedom of the press & \\
& Freedom of expression & \\
& Freedom to participate in public discussion & \\
& Social justice & \\
& "the importance of taking part in the life of the community" & \\
& (Sen, 2000, p. 5)
\end{tabular}

Social opportunity Access to education, healthcare, social security,

Sen and Dreze (1995) and democratic institutions

Social exclusion

Social structures and political processes that impact access to power and resources

Gore and Figueiredo (1997)

Note: Common elements of the definitions are in bold type. 
long to, such as work, school, church, and social groups. Linking capital involves more distant relationships with people, separated not only by their location, but also by different backgrounds and experiences.

Depending on the type of social capital, access to resources differs. Bonding ties, because they involve stronger trust relations, are normally associated with greater access to resources, including information. In this respect, the literature has found a relationship between social capital and informational benefits. For example, Loury (1977) found that black youth are disadvantaged because of a lack of information and experience regarding job opportunities, whereas others might have access to such information from parental connections to the labor market.

Using data from the Chicago labor market, Rees (1966) was perhaps the first to demonstrate the importance of informal channels when looking for a job. These channels, which include referrals from employers and other employees, along with other sources, accounted for about $50 \%$ of white-collar hires and more than $80 \%$ of blue-collar hires. Other researchers have found that informal networks lead at least to a higher frequency of job offers to applicants (Holzer, 1987, 1988). Similarly, Lin's social resource theory suggests that the frequent use of one's social capital leads to better job outcomes (Lin, 1999).

A social linking network beyond one's local community can also confer economic benefits. As Stiglitz (1998) indicated, complex economic systems are made out of social structures, some of which may need to be changed for development to occur. In the same way that trade expands access to markets, social connections beyond one's local community can expand opportunities for economic activity. They can lead, for example, to an increase in clients, access to suppliers to obtain more favorable prices and benefits, and access to capital. A community able to expand its social capital beyond its geographic area does not have to rely on a single market; it can take advantage of a broader and a more diverse set of needs and economic capabilities. A diverse social network can expand the pool of suppliers and customers for one's products. We find evidence of this in work by Fafchamps and Minten (2001) on the agricultural trade. They found from examining a network of business contacts used by traders that social capital had a significant impact on the traders' output; namely, it increased their factors of production (e.g., greater working capital, manpower, etc.). With survey data from 600 to 800 traders from Madagascar, Malawi, and Benin, Fafchamps and Minten (2001) also found that a trader's business contacts reduced individual transaction costs when conducting trade, providing evidence of the power of social relations. Similarly, a study by Kalnins and Chung (2006) found that among clusters of Gujarati immigrant entrepreneurs in the US lodging industry, group members helped each other to succeed. It is also clear from the literature on disadvantaged communities that close connections facili- tate cooperation and the exchange of goods and services among clusters of kin, as documented by Stack's ethnographic research on black families (Stack, 1974). However, these strong ties can also lead to self-segregation, resulting in social exclusion, which can restrict access to resources not available within close social circles.

Our social relationships are crucial because, as individuals aggregate in groups, these groups develop shared identities based on values and beliefs, and the resulting relationships provide access to resources and opportunities (Narayan, 2002). Thus, depending on their composition, different groups have access to different resources. If a group does not have access to many resources, it can compensate for this weakness by accessing resources from other groups.

From a developmental perspective, a problem emerges when portions of a population find themselves socially excluded, meaning that they are unable to participate in the social, economic, cultural, and political life of their country. Social exclusion happens because the ties that bind a group together can exclude those who belong to other social groups with whom they have little in common. Those without access to resources (e.g., jobs, capital, knowledge, etc.) are more likely to be excluded from the economic and political activity of a country (Narayan \& Pritchett, 1999); therefore, social exclusion can lead to social deprivation and limited social capital.

\subsection{Geography and Social Capital Formation}

We tend to believe that social relationships happen in a disorganized manner, but in fact there are easily identified tendencies. For example, for certain groups, the decision about where to live depends on many factors. One, and perhaps the most important, is the cost of living. People with low incomes are naturally going to select more affordable housing (Margo, 1992). Proximity to work is another criterion (Thurston \& Yezer, 1994), and whether or not people share similar backgrounds. This latter phenomenon is well known in the economics literature and was best shown by Schelling (2006). We cluster, the author argues, because of our tendency to try to be with people who are like us, a phenomenon known as homophily. However, simple location preferences like these can lead to segregation. Wealthy people tend to live together, as do people from similar ethnic backgrounds. This leads to self-selection effects, which can affect a community's social capital.

In the academic literature, the relationship between social capital and geography is termed the geography of opportunity, which conveys the notion that a person's life outcomes are affected by the place where they live (Rosenbaum, 1995). In certain locations, this can lead to social exclusion, which Atkinson and Hills (1998) define as "exclusion from a particular society, at a particular place and time."

Segregation can increase economic inequality as, invariably, some groups have access to more and better 
resources, information, and opportunities. In resourcerich communities, members prosper, while resourcepoor locations suffer from deficiencies in all of these areas, which can put residents at a disadvantage, essentially perpetuating and exacerbating their poor economic circumstances.

Up to this point, the literature presented appears to suggest that communities, due to personal preferences (homophily), ends up "de facto segregated," when in fact there are other forces that also result in segregated and disadvantaged communities, namely, government policies. In the US, there are innumerable examples of black families being denied mortgages, refused access to housing subsidies, and forced into segregated neighborhoods on the basis of race (Rothstein, 2017). In Rwanda, the focus of this study, discussions about ethnicity are controversial, given the country's recent history of genocide. There are thus no official statistics on the distribution of tribes or clans. However, there is no doubt that the Tutsis and Hutus have experienced certain territorial privileges at different times in the history of the country (Freedman, Weinstein, \& Longman, 2006). For the purpose of this study, the lack of ethnic data and the fact that districts encompass more than one ethnicity, make it unfeasible to discuss social capital formation based on race.

Geographically clustered communities rely on bonding social capital and on strong trust relationships, which can provide both financial and emotional support. The extent to which bonding links can support the community depends on the amount of resources that it commands collectively. If resources are limited, the community can go only so far economically, at which point it has to rely on linking capital. Beyond this set of relationships, the community can gain further access to resources by expanding its network to people it does not know on its own, but through others (bridging capital) who can facilitate the acquisition of resources.

Mobile phones are almost ubiquitous, even in poor countries (Williams, Mayer, \& Minges, 2011) however, the mobile revolution does not seem to have yet made enough progress to reduce income disparities (Polèse, 2010). If technology were the solution to our wealth problems, Polèse (2010) reflected, the information revolution would have made economic disparities disappear. In our case, even though the emergence of technologies has made distance less determinant, we wished to know if mobile technologies have enabled people of different economic status to communicate and enhance their social capital and to determine if mobile phones enable people to expand their social capital beyond their geographical communities, from inter-community to extracommunity networks (Woolcock, 1998). It should be noted, however, that in the formation of social capital, mobile communication is the medium that allows for people to form ties and norms that bind individuals together. The manner in which this happens-namely, whom individuals choose to socialize with-is what even- tually leads to the development of trust relationships and the sharing of the information and resources that are needed to make both economic and political decisions that enhance their welfare. We thus wished to determine if linking capital is being formed across geographically distant communities.

On the basis of the literature, we posed the following hypotheses:

H1: The use of mobile phones will expand people's networks beyond their geographic boundaries.

$\mathrm{H}$ 2: The richer a geographic community is, the more calls it will make and receive.

\subsection{Mobile as a Technology for Social Capital Expansion}

The International Telecommunications Union (ITU) estimates that in 2018 there were more mobile phone subscriptions than the total world population, with a penetration of $107 \%$ (ITU, 2018). In Africa, this rapid ICT deployment has been considered a communication or mobile revolution that is capable of overcoming infrastructure barriers and supporting the long-term economic development of countries (Williams et al., 2011). The rapid adoption of ICT has thus generated enthusiasm among researchers regarding the expansion of mobile phones among the poor, which promises to support their well-being.

Mobile phones can help reduce the transaction costs associated with time and the monetary costs entailed by meeting acquaintances in person. However, while this technology has the potential to greatly enhance the social, and thus economic, opportunities of the poor, the findings about this relationship are often contradictory. Some studies have found a positive relationship, others a negative one, and yet others a neutral one. In other words, it is unclear whether mobile technologies have been able to replicate existing ties or expand a person's social capital, or whether they might even reduce one's connections with others.

Many have argued that mobile phones are a tool used simply to maintain one's existing social networks (Scott, Garforth, Jain, Mascarenhas, \& McKemey, 2005) and that their use is mainly to keep in touch with family and friends (Zainudeen, Samarajiva, \& Abeysuriya, 2006). This is evidenced in multiple studies. Elder, Samarajiva, Gillwald, and Galperin (2013) noted, for example, that "mobile phones allow the poor to stay in contact with farflung relatives they depend on for remittances." Similarly, a study of mobile phone lists of poor people in Jamaica revealed that family and kin were the most called including relatives living abroad (Horst \& Miller, 2005). Using observations of mobile conversations in public places, Ling (2008) found that mobile phones allow for the development of stronger ties and the formation of rituals among family and friends who may not be geographically close. Wei and Lo (2006), in a survey of college students, found that strong bonds with family and friends and the need 
to express affection were the main reasons for their regular communications, which is to say that bonding social capital had already been established. In this respect, Haythornthwaite (2002) has argued that telephone conversations are more likely to happen when the relations are already strong.

Other scholars have uncovered a positive relation between the use of mobile phones and social capital. Conducting ethnographic work, Katz (2011) concluded that phones help to build social capital. Using semi-structured interviews with refugees in South Africa, Bacishoga, Hooper, and Johnston (2016) found that mobile phones played a positive role in developing bridging social capital and facilitating the users' social and economic integration. A more comprehensive study by Donner (2006) investigated the use of mobile phones by micro-entrepreneurs in Kigali, Rwanda. By analyzing calling patterns, the author investigated how mobile phones expanded the social networks of micro-entrepreneurs. Using a survey, six interviewers visited mobile phone owners in their shops and, taking advantage of their phone logs, asked them questions about each contact in the listings of incoming and outgoing calls and in their SMS feeds. He found that: (1) there was an inverse relationship between the phone owner's level of education and the proportion of business calls; (2) having a landline at home showed a negative correlation with the amount of business calls; (3) the younger the user, the greater the likelihood that their call partner was new to the network; and (4) newer phones registered a lower proportion of business calls, supporting the hypothesis that earlier adopters of mobile phones would have more business calls. Therefore, Donner (2006) showed that mobile phones were being adopted first for business-related purposes; that is, entrepreneurs (micro-entrepreneurs) were purchasing their first phone to expand their business through new contacts.

Other authors have found more neutral or nuanced relations. For example, Eagle, Macy, and Claxton (2010), who used call records for the first time, found that poorer regions in England experienced a higher-thannational-average call volume but had the lowest spatial diversity scores in the country. The prosperous areas had average calling patterns but much more spatially diverse networks than the national average. Rainie and Wellman (2012) and Campbell and Kwak (2011) found that, although mobile phones were positively related to social activity, there was little evidence that they supported the development of "weak ties" in order to bridge relationships.

A study by Yang, Kurnia, and Smith (2011), using mobile logs, found that mobile phones are a useful tool for enhancing a social network. This, however, depends on the type of user. The authors classified users into three categories: (1) passionate users, who are enthusiastic and active and regard their phones as an important tool for their social life; (2) neutral users, who find their phones useful but not critical; and (3) passive users, who use phones for instant communication and tend to receive, more than initiate, calls and messages. As may be expected, the more passionate and active users are, the more they use their phone to organize activities, and they feel comfortable asking for support or help. These passionate users maintain both bonding and linking ties, while more passive users maintain mostly close-bonding relationships. Access to resources, they found, is also related to a person's use patterns.

There are also a few authors who have found a negative relationship between mobile phones and social capital. Galperin and Mariscal (2007) noted, for example, that poor people place few calls. Srivastava's (2005) review of the mobile use literature, for example, argues that mobile phones are contributing to the fragmentation of households, although she does not elaborate on how this happens. She further indicates that, while there has been an increase in spontaneous mobile communication, it appears to be reducing the quality of face-to-face interactions. A longitudinal study of relationships involving self-reported mobile communications with people in Karala, India, found a significant reduction of all types of relations-family, friends, and co-workers (Palackal et al., 2011).

It should be noted that the variability of the findings can be attributed to differences in the methods used to establish the relationship between the use of mobile phones and social capital. Some scholars used surveys and others, observations or call logs. Only one other study used call records to measure economic development. Thus, by connecting data with the geographic locations of calls, this study complements and enhances these previous contributions, determining if and how mobile phones are able to expand the social capital of a community and identifying the types of relations that this technology enables. In particular, we aimed to determine if mobile phones are helping to forge relationships among the different economic regions of Rwanda in ways that support the expansion of social capital.

Based on the literature, this study set out to test the following hypothesis:

H3: The use of mobile phones will expand people's networks beyond their income bracket.

\section{Data and Methods}

The main data for our analysis come from Rwanda's largest telecommunication operator and cover the period from 1 July 2014 to 31 March 2015. The dataset contains more than three billion CDRs, which include information on calls and SMS exchanged on the network during that period. We used four attributes for every call or SMS: (1) a timestamp of when the event happened; (2) an anonymized identifier for the event initiator, meaning the person who sent the text message or made the call; two identifiers for (3) the network cell of origin; and (4) the destination. We do not consider other attributes, 
such as the receiver, whether an event was a call or a text message, the duration of a call, and so forth.

The dataset captures events that occurred over a network with 3,006 cells mounted on 513 towers. However, we have the location data for only 2,258 cells (see Figure 1). Twenty-four cell numbers were invalid, and 724 were not associated with any single district. Nonetheless, the identifiers reveal that four cells were in the Eastern Province, 664 in Kigali (Rwanda's capital and largest city), 17 in the Northern Province, nine in the Southern Province, and 30 in the Western Province. The highest number of unidentified cells was in the capital city. This might be due to the fact that a number of cells are mounted on building tops, as opposed to towers. Figure 1 shows the locations of the cell towers from which the data were collected.

In addition to the above dataset, we obtained data from the fourth Integrated Household Living Conditions Survey, conducted by the NISR (2015). This survey covered the years 2013 and 2014 and focused on poverty, measured in terms of consumption. Of particular interest to our study were the indices of poverty and extreme poverty for each district. The poverty line in Rwanda was computed in the report by using a food-calorie consumption of 2,500 Kcal per adult equivalent per day, plus expenditures of $\approx 66 \%$ of the income designated for food on non-food items. Computed this way, the percentage of people in poverty in various districts of Rwanda ranged from $16.3 \%$ to $62.0 \%$, with an average of $39.3 \%$, and the percentage of people in extreme poverty ranged from $5.7 \%$ to $39.2 \%$, with an average of $16.2 \%$.

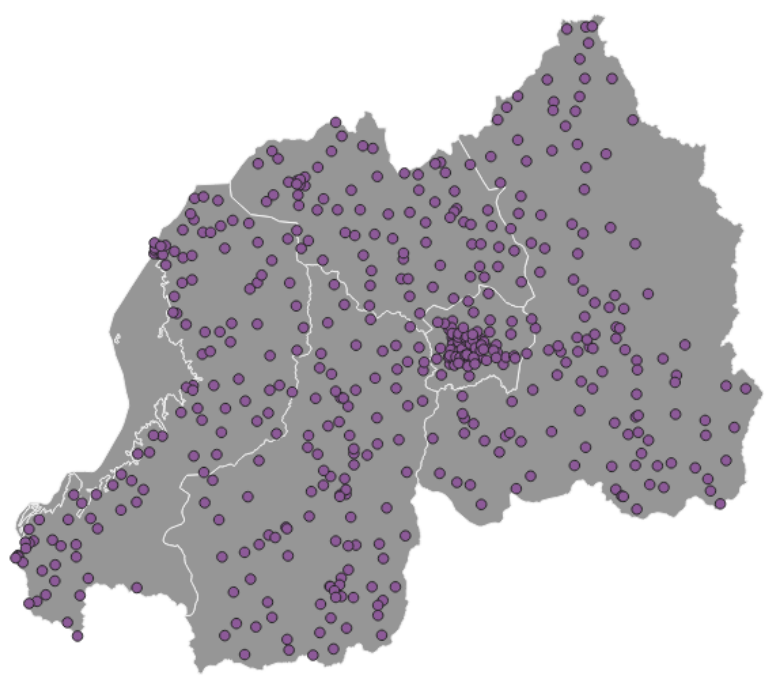

Figure 1. Locations of cell towers. Lines indicate the boundaries of the four provinces and the city of Kigali. Source: Authors.

To understand whether mobile phone communication helped people expand their network (their social capital) beyond the people in their districts, we grouped the districts into four levels of poverty by using standard deviation from the national mean of the percentage of people living in poverty. Table 2 presents a data summary of the districts, grouped by the percentages of people living in poverty. Figure 2 graphically shows the districts based on those groups.

Table 2. District data by poverty category.

\begin{tabular}{lccc}
\hline Groups by poverty level & Range of people living in poverty & Number of districts & Average district population size \\
\hline Lowest poverty level & $16.3 \%-28.5 \%$ & 6 & 355,134 \\
Low-mid poverty level & $28.5 \%-39.3 \%$ & 8 & 353,231 \\
Mid-high poverty level & $39.3 \%-50.2 \%$ & 11 & 345,288 \\
Highest poverty level & $50.2 \%-62.0 \%$ & 5 & 352,230 \\
\hline
\end{tabular}

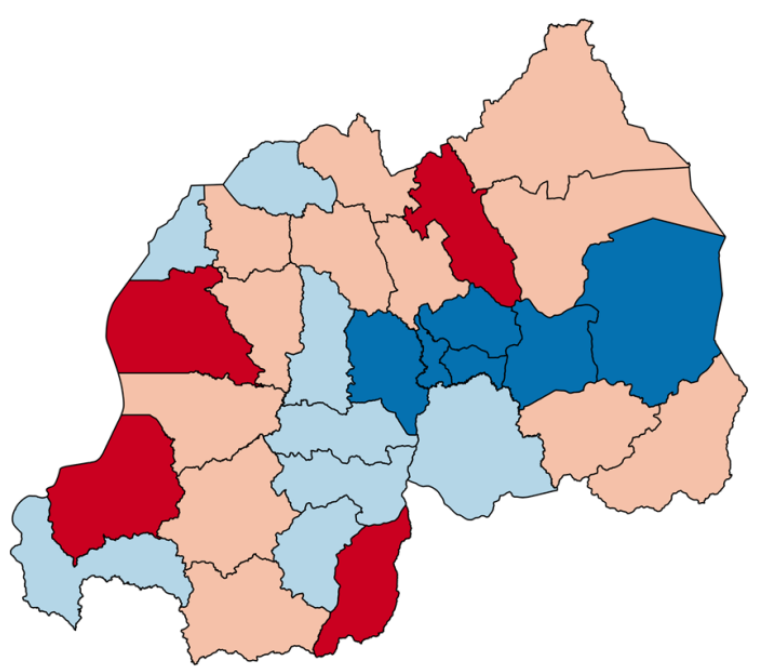

Legend

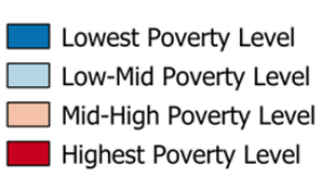

Figure 2. Four levels of poverty in the districts, from the least poor (in blue) to the poorest (in red). Source: Authors. 
It should be noted that we did not have detailed data about individuals' income levels; therefore, this study focuses on people who were experiencing poverty as indicated by the district's poverty data, and on whether they were calling people who were a bit less poor.

\section{Results}

Using the dataset of CDRs, we summed the number of incoming and outgoing calls for each district. Since the districts have different population sizes, we computed the total number of incoming and outgoing calls per capita during the nine months covered by the CDRs dataset, so that we could compare these numbers across districts.

To analyze the relationship between social capital and poverty level and understand whether people expanded their social network beyond their geographical boundaries and income strata, we first compared the number of intra-district calls to that of inter-districts calls. Inter-district calls represented only 3.8\% (more than 106 million calls) of the total number of calls, while the rest were intra-district calls (96.2\%). This low number of inter-district calls indicates that people mostly used phones to stay in touch with other people in their area and did not expand their social networks beyond their districts. Figure 3 shows the directions of calls in each district category.
Figure 3 indicates that inter-district calls from the least poor districts vastly terminated in other least poor districts. Interestingly, the inhabitants of districts with low-mid-poverty levels mostly interacted with people living in the poorest districts, though the latter are geographically surrounded by districts in the "mid-high poverty level" category (see Figure 2). Therefore, it seemed that geographical proximity had only a limited influence on the volume and direction of calls. To explore the influence of the poverty of an area on the volume and direction of its inhabitants' calls, we calculated correlations and performed linear regressions on the calling patterns observed in the CDRs dataset against the poverty levels of the different districts. Because we were working with a massive dataset, we could not rely on standard statistical packages. Therefore, the regressions used for this analysis were done using Apache Spark, "a fast and general engine for large-scale data processing" (Apache, 2018), as well as MLib, its library for machine learning. We deployed Apache Spark on a local cluster consisting of six servers, totaling 20 processing cores and 200 gigabytes of memory (RAM).

Table 3 shows the correlations between calling patterns, adjusted per capita, and the levels of poverty and extreme poverty in the different districts.

The poverty levels of the districts were strongly negatively correlated with the number of incoming calls per

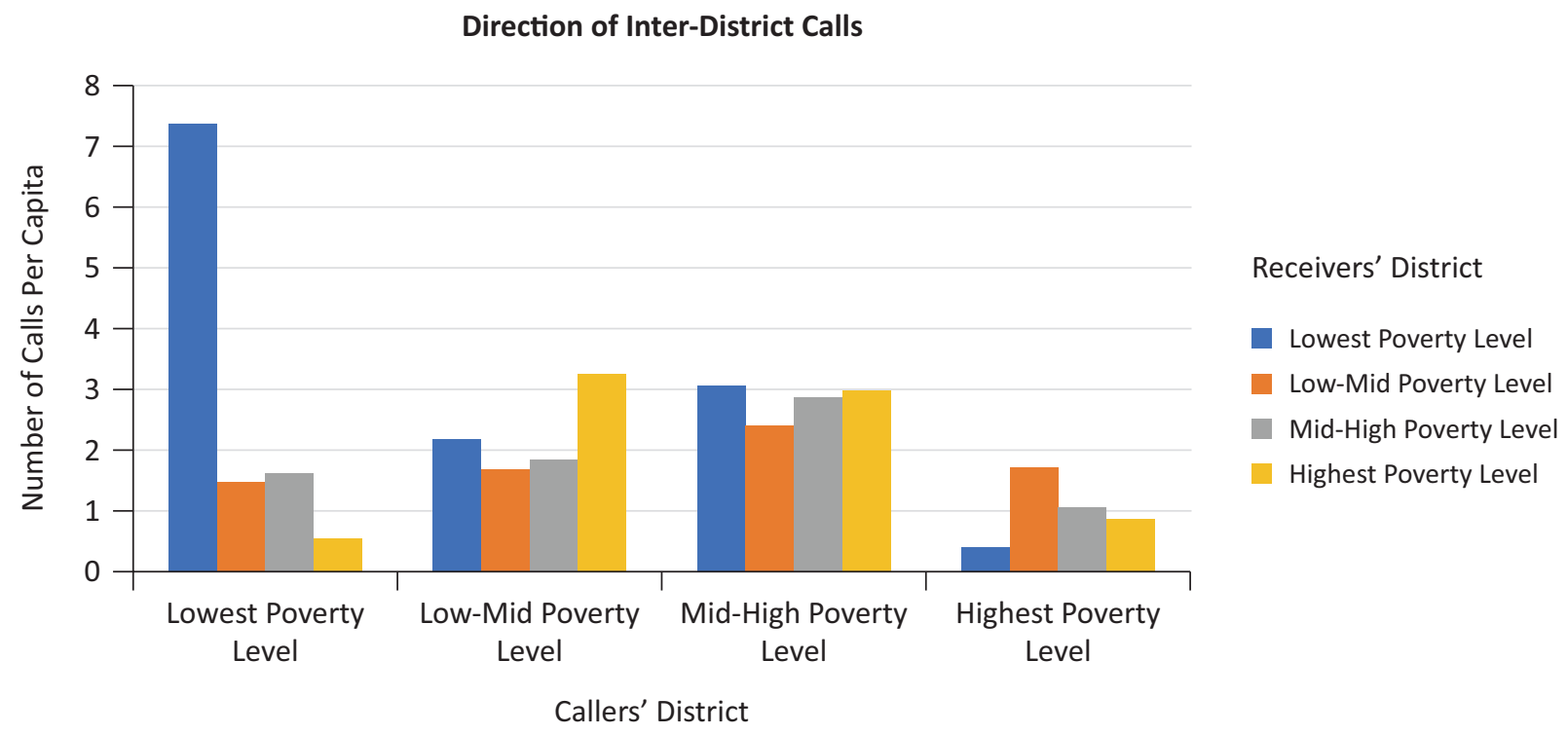

Figure 3. Average number and direction of inter-district calls per capita for each poverty category. Source: Authors.

Table 3. Correlations between poverty levels and calling patterns.

\begin{tabular}{|c|c|c|c|c|}
\hline & Incoming calls & Outgoing calls & Poverty & Extreme poverty \\
\hline Incoming calls & 1 & & & \\
\hline Outgoing calls & $0.963^{*}$ & 1 & & \\
\hline Poverty & $-0.603^{*}$ & $-0.596 *$ & 1 & \\
\hline Extreme poverty & $-0.419 * *$ & $-0.468^{*}$ & $0.899 *$ & 1 \\
\hline
\end{tabular}

Notes: ${ }^{*} p$-value $\leq 0.01 ;{ }^{* *} p$-value $\leq 0.05$. 
capita $(r=-0.603, p \leq 0.000)$ and the number of outgoing calls per capita $(r=-0.596, p \leq 0.001)$. However, the levels of extreme poverty were less strongly correlated with the number of incoming calls per capita $(r=-0.419$, $p=0.02$ ) and the number of outgoing calls per capita ( $r=-0.468, p=0.01$ ). These correlations suggest that there is a relationship between poverty and the number of calls per capita.

To investigate whether people were reaching out to richer areas when they made calls outside their districts, we conducted a regression on the dataset containing only inter-districts call, with more than 106 million records. The models sought to predict the poverty level of the receiver's district by using the percentages of people living in poverty and extreme poverty in the caller's district, as follows in Equation 1:

$$
\mathrm{RP}=\alpha+\beta_{1} \mathrm{CP}+\beta_{2} \mathrm{CEP}
$$

Here, RP is the poverty level of the receiver's district, CP is the poverty level of the caller's district, and CEP is the extreme poverty level of the caller's district. We included both the measures of poverty and extreme poverty since their ratios differ from district to district. Thus, these two measurements have different impacts on the volume and direction of calls. This was an attempt to determine the poverty level of the receiver.

Since we were interested in exploring inter-district calling patterns between districts with different poverty levels, we ran a series of regressions aimed at revealing the relationship between the poverty level of the receiver's district and that of the caller's district, based on the four poverty categories (see Figure 3). Table 4 shows the resulting coefficients.

This series of regressions indicates that, except receivers in districts with the least number of people living in poverty (i.e., the lowest poverty levels), when receivers get calls from another district, it is likely to be from a district with fewer poor people. This can be seen in the negative values of $\beta_{1}$. For example, people living in districts with the highest poverty levels, on average, received calls from people living in areas that had 1.23 times fewer poor people. Interestingly, recipients, particularly those in the middle categories (lowmid and mid-high poverty levels), tended to receive calls from districts with more people living in extreme poverty than their own districts. For example, people living in extreme poverty reached out to people in the middle categories, particularly those in the mid-high poverty level $\left(\beta_{2}=0.75\right)$. Thus, recipients in the middle-poverty categories (low-mid and mid-high poverty levels) received calls from areas with fewer poor people $\left(\beta_{1}=-0.49\right.$ and $\beta_{1}=-0.67$, respectively). The regression models in Table 4 show that people of higher means (category 1 ) received minimal calls from the extremely poor $\left(\beta_{2}=-0.39\right)$ and more calls from people who were better off $\left(\beta_{1}=1.25\right)$. This indicates that the least-poor people were calling others of similar economic status. Results further indicate that people in middle categories 2 and 3 were receiving calls not only from people in richer areas, but also from people in extremely poor areas (with 0.54 and 0.75 times more extremely poor people, respectively). In this manner, they acted as a bridge between the lowest and highest poverty-level districts. This can be seen in Figure 3, which shows that people in the middle economic categories had more interactions with people living in areas on the two extreme ends of the poverty spectrum, whereas people in low-poverty districts had minimal interaction with those in areas experiencing the highest poverty levels, and vice-versa.

\section{Discussion and Proposed Framework}

The results of this study provide some insights into the manner in which mobile phones support a community's ability to build social capital. First, the vast majority (96.2\%) of phone calls took place between people living within the same geographic area. This finding suggests that mobile phones do not necessarily expand people's social capital by extending their network across distances. Instead, it appears that mobile phones reinforce existing relationships between people in close geographic spaces. This low number of calls between districts also mirrors the low levels of internal migration in Rwanda, as demonstrated by Blumenstock (2012). The low levels of internal migration would limit the spread of people's social networks to other districts, thereby restricting their social capital as well, particularly when they live in areas with a high degree of poverty. We thus reject $H 1$, where we expected mobile phones to be able to expand people's network beyond their geo-

Table 4. Results of linear regressions (see Equation 1) for each category of receiver poverty level.

\begin{tabular}{lcccc}
\hline & \multicolumn{3}{c}{ Receiver's district poverty category } \\
\hline & 1 & 2 & 3 & 4 \\
\cline { 2 - 5 } & $\begin{array}{c}\text { Lowest poverty } \\
\text { level }\end{array}$ & $\begin{array}{c}\text { Low-mid poverty } \\
\text { level }\end{array}$ & $\begin{array}{c}\text { Mid-high poverty } \\
\text { level }\end{array}$ & $\begin{array}{c}\text { Highest poverty } \\
\text { level }\end{array}$ \\
\hline Constant $(\alpha)$ & $4.42^{*}$ & $50.86^{*}$ & $55.43^{*}$ & $94.46^{*}$ \\
Caller's poverty $\left(\beta_{1}\right)$ & $1.25^{*}$ & $-0.49^{*}$ & $-0.67^{*}$ & $-1.23^{*}$ \\
Caller's extreme poverty $\left(\beta_{2}\right)$ & $-0.39^{*}$ & $0.54^{*}$ & $0.75^{*}$ & $0.49^{*}$ \\
\hline
\end{tabular}

Note: ${ }^{*} p$-value $=0.000$. 
graphic boundaries. In fact, we found the opposite to be the case. People are staying within their boundaries, and maybe within their linking networks.

Our results also reveal that the number of incoming and outgoing calls per capita is significantly and inversely correlated with poverty levels, but less so with extreme poverty levels. This would suggest that the use of mobile phones has an impact on people's network of relations, and consequently on their economic lives, only when they already have the basic necessities covered. It could be that people in extreme poverty, who do not have guaranteed access to basic necessities such as food and shelter, are too preoccupied with daily survival and too lacking in resources to plan for the long term, whereas people at the poverty level have their basic necessities covered and, thus, have more time to use their mobile phones to network and access more resources to lift themselves out of poverty. The results thus fail to support H3, where we also expected mobile technologies to enable people to expand their social networks to reach people in higher income brackets. The high number of intra-district calls suggests that people, for the most part, are not talking to people in districts with higher incomes. It should be noted, however, that those who call outside of their districts do call communities in the middle-income brackets, that is, in categories 2 and 3 . Thus, this partially supports $\mathrm{H} 2$, about expecting the richer geographic communities to receive more calls, since we would have expected the first category (i.e., the least poor areas) to receive the most calls. However, unlike those in other categories, people living in districts with the highest levels of poverty make most of their calls to people in categories 2 and 3 . This suggests that the middle poor make greater efforts to expand their social network to potentially get access to resources and enhance their economic well-being, unlike the extreme groups, who mostly communicate amongst themselves.

Nonetheless, a deeper analysis of the direction of calls shows that when people in areas at the extreme ends of the poverty scale (lowest and highest poverty level) call outside their district (inter-district calls), they tend to call people in the middle categories. This suggests that these middle categories play a bridging role between categories 1 and 4 .

From the calling patterns we observed, we propose a framework that captures the different roles that mobile communication could play within the different economic strata of the society of a developing country and the patterns of calls we observed. The objective is to tie the literature on social capital to that of development by identifying at a more granular level the impact that technology may have on social capital and the roles that these social relations might play across different income levels. We think that technology is reinforcing existing face-to-face interactions, while recognizing the potential functions that connections with less poor districts might serve. Table 5 presents our proposed classification of the calling patterns that we observed.

Intra-district calls play a potentially different role, depending on the income level. In districts with extreme poverty, their purpose is bonding, which can provide emotional as opposed to economic support, given that residents in these areas have little to offer by way of material resources. The middle districts could provide not only emotional, but also limited economic support, particularly in times of emergency.

Better off communities may not communicate as much outside their group because they may already have what they need or want. They may not have an incentive, at least not an economic one, to contact people outside their group unless it is, we believe, to purchase goods and services that a community of a different income status is providing. For this group, their slightly higher income is significantly correlated more with receiving calls than making them. One could suggest that their in-group communication could be simply for status maintenance.

Given the low number of calls that we see going outside a geographic area, the only group that has a possibility of fostering economic development consists of those with middle levels of poverty, who have more means and economic incentives to take advantage of mobile communication technologies to enhance their resources. This group appears to be more capable of fostering both bridging and linking capital to create greater opportunities for themselves. We suspect that calls made by this group in the middle-income bracket to people in extreme poverty are probably to provide resources instead of to obtain them.

Intra-district calls usually go from the poor to the middle poor, and vice versa. This may be because it is unlikely that a person in extreme poverty would interact with someone with a considerably higher income. Thus, both groups communicate towards the middle. The people in the middle are more likely to communicate with people in the higher bracket (through work, trade, etc.) and people in the lower bracket (e.g., through family links and re-

Table 5. Functional roles of mobile phones by poverty category.

\begin{tabular}{llll}
\hline Calling pattern & Income levels & & \\
\hline \multirow{3}{*}{ Inside their district } & Extreme poverty & Middle-level poverty & Lower-level poverty \\
& bonding, & bonding, & bonding, \\
Outside their district & social coordination & economic relief & status maintenance \\
& linking, & linking, & linking, \\
& support & empowering & social/business enabler \\
\hline
\end{tabular}


source support) are more likely than people at both extremes are to communicate with each other. For all of the groups, in-group communication-those between people with similar income-is more likely to be of the bonding type, while bridging communication with a higher income group could be to gain access to resources, and in the case of the poor, resources that could guarantee their survival.

\section{Conclusion and Policy Implications}

Mobile phones are primarily a communication technology, yet previous studies have been inconclusive, given their different focuses and methodologies. This study complements that work by establishing a connection with a caller's and receiver's geographic location and economic status. This study analyzed the calling patterns of a sizable section of the Rwandan population to determine if this technology has helped to expand poor people's social capital and, in turn, their access to resources that could improve their welfare.

Sadly, the vast majority of mobile phone communications took place within the geographic areas where the poor lived, and consequently between people of similar income levels. With the exception of the middle group, most groups did not seem to be developing many bridging or linking ties, which, for the poor, has a negative impact. Given the correlation we discovered between income and social capital, governments could take advantage of this seemingly random set of connections to provide their communities with opportunities for people to expand their connections beyond their natural bonding social capital. In turn, this would effectively create a system that can lead to a more purposeful development of relationships between people from different economic strata.

\section{Acknowledgments}

This research was supported in part through computational resources provided by Syracuse University, supported by the NSF award ACl-1541396.

\section{Conflict of Interests}

The authors declare no conflict of interests.

\section{References}

Abraham, R. (2006). Mobile phones and economic development: Evidence from the fishing industry in India. In Proceedings of the 2006 International Conference on Information and Communication Technologies and Development (pp. 48-56). Washington, DC: IEEE Computer Society.

Amel, F. (2014). Towards a safer city-Sexual harassment in greater Cairo: Effectiveness of crowdsourced data. HarassMap. Retrieved from https://harassmap.org/ storage/app/media/uploaded-files/Towards-A-
Safer-City_executive-summary_EN.pdf

Apache. (2018). Apache Spark ${ }^{\mathrm{TM}}$ : Unified analytics engine for big data. Apache Spark. Retrieved from https:// spark.apache.org

Atkinson, A. B., \& Hills, J. (1998). Exclusion, employment and opportunity (LSE STICERD Research Paper No. CASE004). London: LSE STICERD.

Bacishoga, K. B., Hooper, V. A., \& Johnston, K. A. (2016). The role of mobile phones in the development of social capital among refugees in South Africa. The Electronic Journal of Information Systems in Developing Countries, 72(1), 1-21.

Blumenstock, J. E. (2012). Inferring patterns of internal migration from mobile phone call records: Evidence from Rwanda. Information Technology for Development, 18(2), 107-125.

Campbell, S. W., \& Kwak, N. (2011). Political involvement in "mobilized" society: The interactive relationships among mobile communication, network characteristics, and political participation. Journal of Communication, 61(6), 1005-1024.

Cibangu, S. K., Hepworth, M., \& Champion, D. (2017). Mobile phones for development: An information case study of mobile phone kiosk vendors in the Congo. Aslib Journal of Information Management, 69(3), 294-315.

Coleman, J. S. (1988). Social capital in the creation of human capital. American Journal of Sociology, 94, S95-S120.

Collins, T. (2019). Mara Group opens Africa's first smartphone factory in Rwanda. African Business. Retrieved from http://africanbusinessmagazine.com/ region/east-africa/mara-group-opens-africas-firstsmartphone-factory-in-rwanda

Donner, J. (2006). The use of mobile phones by microentrepreneurs in Kigali, Rwanda: Changes to social and business networks. Information Technologies \& International Development, 3(2), 3-19.

Eagle, N., Macy, M., \& Claxton, R. (2010). Network diversity and economic development. Science, 328(5981), 1029-1031.

Elder, L., Samarajiva, R., Gillwald, A., \& Galperin, H. (2013). Information lives of the poor: Fighting poverty with technology. Ottawa: International Development Research Centre.

Fafchamps, M., \& Minten, B. (2001). Social capital and agricultural trade. American Journal of Agricultural Economics, 83(3), 680-685.

Freedman, S., Weinstein, H., \& Longman, T. (2006). The teaching of history of Rwanda: A participatory approach. Berkeley, CA: Human Rights Center, University of California Berkeley.

Galperin, H., \& Mariscal, J. (Eds.). (2007). Digital poverty: Latin American and Caribbean perspectives. Ottawa: International Development Research Centre.

Goodman, D. (2005). Linking mobile phone ownership and use to social capital in rural South Africa and Tanzania. Intermedia, 33(4), 26-42. 
Gore, C., \& Figueiredo, J. B. (Eds.). (1997). Social exclusion and anti-poverty policy: A debate. Geneva: International Labour Office.

Haythornthwaite, C. (2002). Strong, weak, and latent ties and the impact of new media. The Information Society, 18(5), 385-401.

Holzer, H. J. (1987). Informal job search and black youth unemployment. The American Economic Review, 77(3), 446-452.

Holzer, H. J. (1988). Search method use by unemployed youth. Journal of Labor Economics, 6(1), 1-20.

Horst, H., \& Miller, D. (2005). From kinship to link-up: Cell phones and social networking in Jamaica. Current Anthropology, 46(5), 755-778.

Islam, M. M., Habes, E. M., \& Alam, M. M. (2018). The usage and social capital of mobile phones and their effect on the performance of microenterprise: An empirical study. Technological Forecasting and Social Change, 132, 156-164.

International Telecommunications Union. (2018, December 7). ITU releases $2018 \mathrm{global}$ and regional ICT estimates [Press Release]. Retrieved from https://www. itu.int/en/mediacentre/Pages/2018-PR40.aspx

Kalnins, A., \& Chung, W. (2006). Social capital, geography, and survival: Gujarati immigrant entrepreneurs in the US lodging industry. Management Science, 52(2), 233-247.

Katz, J. E. (2011). Magic in the air: Mobile communication and the transformation of social life. Piscataway, $\mathrm{NJ}$ : Transaction Publishers.

Lai, G., \& Siu, Y. M. (2006). Residential mobility and social capital in urban Shanghai. Asian Journal of Social Science, 34(4), 573-599.

Lee, D. (2009). The impact of mobile phones on the status of women in India (Unpublished Doctoral dissertation). Stanford University, California, USA. Retrieved from http://citeseerx.ist.psu.edu/viewdoc/ download?doi=10.1.1.647.792\&rep=rep1\&type=pdf

Lin, N. (1999). Building a network theory of social capital. Connections, 22(1), 28-51.

Ling, R. S. (2008). New tech, new ties. Cambridge, MA: MIT Press.

Loury, G. (1977). A dynamic theory of racial income differences. Women, Minorities, and Employment Discrimination, 153, 86-153.

Margo, R. A. (1992). Explaining the postwar suburbanization of population in the United States: The role of income. Journal of Urban Economics, 31(3), 301-310.

Matous, P., Tsuchiya, T., \& Ozawa, K. (2011). Farmers' access to resources via networks in remote rural areas with mobile phone reception: Creating a resource battery for a mountain tribe in south India. Rural Society, 20(2), 174-186.

Narayan, D. (2002). Bonds and bridges: Social capital and poverty. In J. Isham \& S. Ramaswamy (Eds.), Social capital and economic development: Well-being in developing countries (pp. 58-81). Northampton, MA: Edward Elgar.
Narayan, D., \& Pritchett, L. (1999). Cents and sociability: Household income and social capital in rural Tanzania. Economic Development and Cultural Change, 47(4), 871-897.

National Institute of Statistics Rwanda. (2015). Rwanda poverty profile report: Results of EICV 4. Kigali: Rwanda Government.

Palackal, A., Nyaga Mbatia, P., Dzorgbo, D. B., Duque, R. B., Ynalvez, M. A., \& Shrum, W. M. (2011). Are mobile phones changing social networks? A longitudinal study of core networks in Kerala. New Media \& Society, 13(3), 391-410.

Polèse, M. (2010). The wealth and poverty of regions: Why cities matter. Chicago, IL: University of Chicago Press.

Putnam, R. D. (2000). Bowling alone: The collapse and revival of American community. New York, NY: Simon and Schuster.

Rainie, H., \& Wellman, B. (2012). Networked: The new social operating system. Cambridge, MA: MIT Press.

Rees, A. (1966). Information networks in labor markets. The American Economic Review, 56(1/2), 559-566.

Rosenbaum, J. E. (1995). Changing the geography of opportunity by expanding residential choice: Lessons from the Gautreaux program. Housing Policy Debate, 6(1), 231-269.

Rothstein, R. (2017). The color of law: A forgotten history of how our government segregated America. New York, NY: Liveright Publishing.

Schelling, T. C. (2006). Micromotives and macrobehavior. New York, NY: WW Norton \& Company.

Scott, N., Garforth, C., Jain, R., Mascarenhas, O., \& McKemey, K. (2005). The economic impact of telecommunications on rural livelihoods and poverty reduction: A study of rural communities in India (Gujarat), Mozambique and Tanzania (Report of DFID KaR Project 8347). London: Commonwealth Telecommunications Organisation.

Sen, A. (2000). Social exclusion: Concept, application, and scrutiny. Mandaluyong: Office of Environment and Social Development Asian Development Bank Retrieved from https://www.think-asia.org/bitstream/ handle/11540/2339/social-exclusion.pdf

Sen, A., \& Dreze, J. (1995). India: Economic development and social opportunity. Oxford: Clarendon Press.

Shen, C., \& Gong, H. (2019). Personal ties, group ties and latent ties: Connecting network size to diversity and trust in the mobile social network WeChat. Asian Journal of Communication, 29(1), 18-34.

Silver, L. (2019). Smartphone ownership is growing rapidly around the world, but not always equally. Pew Research Center. Retrieved from https://www. pewresearch.org/global/2019/02/05/smartphoneownership-is-growing-rapidly-around-the-world-butnot-always-equally

Silver, L., Smith, A., Johnson, C., Jiang, J., Anderson, M., \& Rainie, L. (2019). Use of smartphones and social media is common across most emerging 
economies. Pew Research Center. Retrieved from https://www.pewresearch.org/internet/2019/ 03/07/use-of-smartphones-and-social-media-iscommon-across-most-emerging-economies

Srivastava, L. (2005). Mobile phones and the evolution of social behaviour. Behaviour \& Information Technology, 24(2), 111-129.

Stack, C. (1974). All our kin: Strategies for survival in a black community. Manhattan, NY: Harper \& Row.

Stiglitz, J. E. (1998). Towards a new paradigm for development. Geneva: United Nations Conference on Trade and Development.

Thurston, L., \& Yezer, A. M. (1994). Causality in the suburbanization of population and employment. Journal of Urban Economics, 35(1), 105-118.

Wei, R., \& Lo, V. H. (2006). Staying connected while on the move: Cell phone use and social connectedness. New Media \& Society, 8(1), 53-72.
Williams, M. D., Mayer, R., \& Minges, M. (2011). Africa's ICT infrastructure: Building on the mobile revolution. Washington, DC: World Bank.

Woolcock, M. (1998). Social capital and economic development: Toward a theoretical synthesis and policy framework. Theory and Society, 27(2), 151-208.

Yang, S., Kurnia, S., \& Smith, S. P. (2011). The impact of mobile phone use on individual social capital. In Proceedings of the 2011 44th Hawaii International Conference on System Sciences (pp. 1-10). Washington, DC: IEEE Computer Society.

Zainudeen, A., Samarajiva, R., \& Abeysuriya, A. (2006). Telecom use on a shoestring: Strategic use of telecom services by the financially constrained in South Asia (Discussion Paper WDR0604, version 2). Lyngby: World Dialogue on Regulation for Network Economies.

\section{About the Authors}

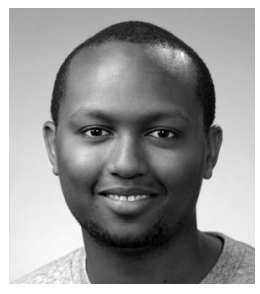

Alain Shema is a PhD Candidate at the Syracuse University's iSchool. His research investigates the use of technology in developing countries. He is particularly interested in using novel data, such as those generated by the use of mobile phones, to understand the socioeconomic lives of people in underserved areas. His current projects explore mechanisms of reducing the high default rates observed in the digital micro-lending industry. He holds an Ms in Information Science and Technology from Carnegie Mellon University.

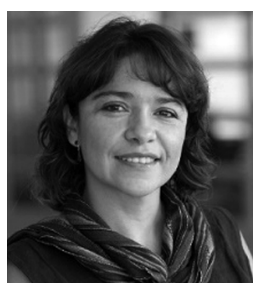

Martha Garcia-Murillo is a Professor of Information Studies at Syracuse University. Her research expertise is about the impact of technology and public policy. Her research focuses on the impact of technology on society. Her empirical and theoretical work has analyzed the effects of technology on the informal sector, on the creation of new firms, and recently, on work. She is also an expert in theory construction and has written and led workshops on the subject. 